\title{
Design and evaluation of neutron howitzer design for the research and education using MCNP5 program
}

- Truong Van Minh

Dong Nai University

- Nguyen Ngoc Anh

- Ho Huu Thang

Nguyen Xuan Hai

Dalat Nuclear Research Institute

- Dinh Tien Hung

Military Institute of Chemical and Environmental Engineering

(Received on $25^{\text {th }}$ November 2016, accepted on $22^{\text {th }}$ May 2017)

\section{ABSTRACT}

In this paper, the design evaluation of a neutron howitzer using for research and education purposes in Training Center at Dalat Nuclear Research Institute is presented. A mixture of paraffin and boron is used as both moderator and absorber in order to shield neutron from the 252Cf source. The howitzer cover which is made from steel shields the gamma-rays caused by the neutron capture reaction of boron. The simulation has been done using the MCNP5 program. The result shows that the design met requirements of usage and radiation safety rules in Vietnam.

Keywords: Neutron howitzer, paraffin howitzer, howitzer design

\section{INTRODUCTION}

Neutron howitzer is an efficient instrument for research and education purposes, which have to use isotope neutron sources such as ${ }^{252} \mathrm{Cf}$ [1]. Neutron howitzer can be classified according to usage purposes or neutron moderators. Two materials, which are mainly used as moderator, are paraffin and water.

In 2011, a water neutron howitzer was established in the Training Center (TC) at Dalat Nuclear Research Institute (DNRI) [2]. This kind of howitzer was very convenient to perform experiments related to neutron moderation and neutron diffusion. Based on the water howitzer, many experiments, such as neutron migration area determination and neutron diffusion length determination were successfully built. However, the structure of the water howitzer was inconvenient to setup shielding experiments, neutron cross-section determination, neutron activation analysis, neutron dose calibration and some others.

Therefore, in order to solve the problem, we decided to design a new howitzer, which uses paraffin as a moderator. The design of the paraffin howitzer must not only be suitable for setting up recommended experiments and ensure radiation safety rules but also take advantage of existing material in the Training Center $\left({ }^{252} \mathrm{Cf}\right.$ source [3] and few hundreds kilogram of paraffin).

In order to evaluate the design, MCNP5 simulation program [4] was used. The results show that this design can be approved to proceed to operation. 


\section{METHOD}

\section{Design of paraffin howitzer system}

An overview of the paraffin howitzer is shown in Fig. 1. The system can be separated into two parts: howitzer unit (1) and sample/detector holding unit (2). These two are put on rails and be movable along the rail (12). The howitzer unit is composed of the howitzer (8) and the frame (5). Vertical position of the howitzer can be changed by two lifts (9). Radioactive source is attached to the howitzer lid (7), and put into the howitzer. A motor (4) fixed on the top of the frame control the source position corresponding with open/close status of the system. A box is also stuck on top of the frame to hold some electric control module. The sample/detector holding is simply a table, which have wheels to move on rails and a lift to change surface vertical position. The sample/detector will be put on the table. Furthermore, wheel locks are equipped to fix position of units.

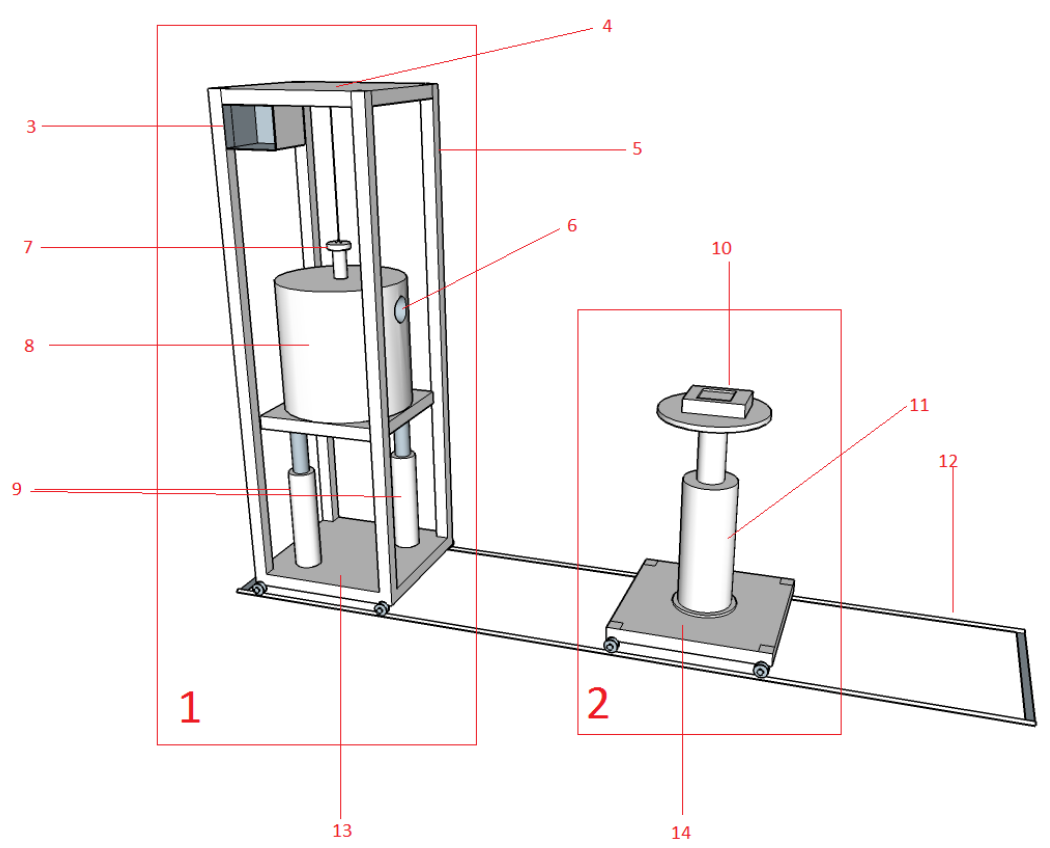

Fig. 1. Overview of neutron paraffin howitzer system

1 - Howitzer unit, 2 - Sample/detector holding unit, 3 - Control box, 4 - Motor, 5 - Howitzer frame, 6 - Beam out position, 7 - Howitzer lid, 8 - Howitzer, 9 - Howitzer lifts, 10 - Sample/Detector holding position, 11 -Sample/detector lift, 12 - Rails, 13 - Howitzer movable base, 14 - Sample/detector moveable base

The detailed structure of the howitzer unit is given in Fig. 2. ${ }^{252} \mathrm{Cf}$ source is attached in the bottom of the howitzer's lid, which is put into the center of the howitzer with $50 \mathrm{~cm}$ diameter and filled by a mixture $80 \%$ paraffin and $20 \%$ carbide boron. The howitzer lid can move vertically to open and close the source. In open status, the neutron beam is collimated by a cone with open angle of about $40^{\circ}$. The cover of the howitzer is made by stainless steel with $2 \mathrm{~mm}$ thickness. The howitzer lid is also filled with paraffin and carbide boron mixture to reduce the radiation dose on top of the howitzer.

\section{Trang 84}


Briefly, the neutron flux into angle $4 \pi$ of the source is about $2.6 \times 10^{7} \mathrm{~Bq}$, therefore, the thickness of the howitzer in this design ensures neutron dose rate at $50 \mathrm{~cm}$ far from the howitzer is less than $10 \mu \mathrm{sV} / \mathrm{h}$. Switching source on/off can be done in safety by a remote control system. The movable design simplifies the setting up of experiments.

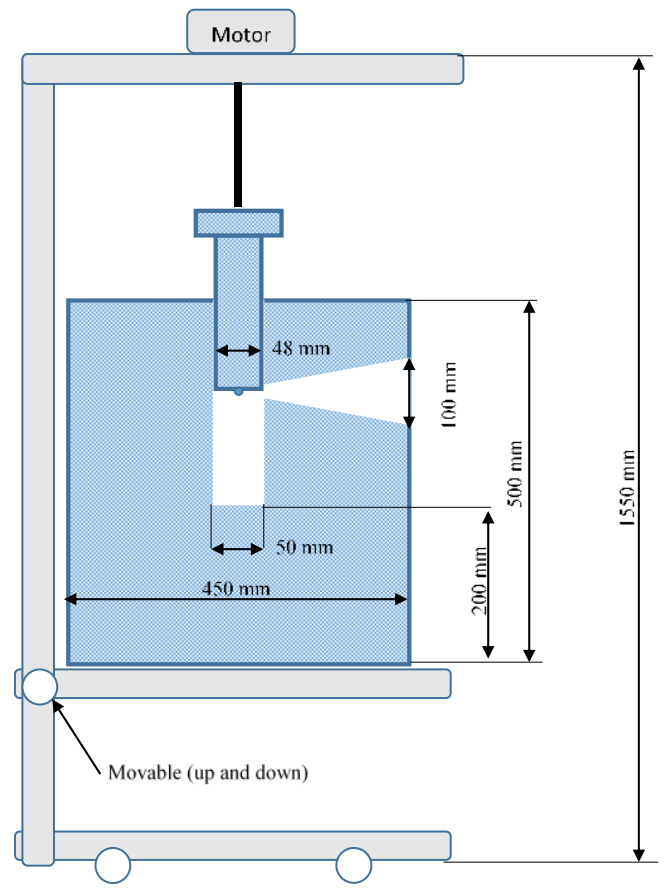

Fig. 2. Detail structure of the howitzer

\section{Simulation}

In order to simplify the simulation process but still ensure the authenticity of the simulation, the howitzer, howitzer lid and ${ }^{252} \mathrm{Cf}$ source were described as detailed as possible but the frame, lifts, sample/detector holding unit, and the other supplementary components were not defined. Mass density and elements ratio of used materials were calculated based on MCNP5 manual [5] and document [6].

\section{${ }^{252} \mathrm{Cf}$ neutron source}

The ${ }^{252} \mathrm{Cf}$ source is completely simulated as described in its certificate [3]. The structure of the source is shown in Fig. 3. The active core of the source is a californium oxide cylinder with $3.4 \mathrm{~mm}$ diameter and $3 \mathrm{~mm}$ length. The source capsule is made by stainless steel.

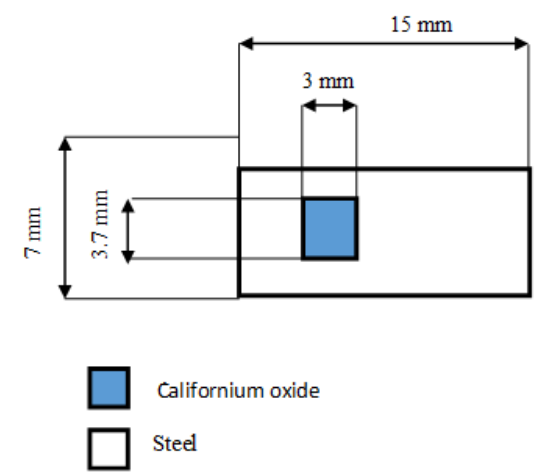

Fig. 3. Structure of ${ }^{252} \mathrm{Cf}$ source [3]

Neutron flux value used in simulation was $2.6 \times 10^{7} \mathrm{n} . \mathrm{s}^{-1}$, approximately the real value of the source at the moment of the calculation, which was $(2.6 \pm 0.2) \times 10^{7}$ n..$^{-1}$.

Energy distribution of ${ }^{252} \mathrm{Cf}$ is a Watt distribution because of the fact that is a spontaneous fission source. MCNP5 program provides a syntax to declare continuum energy distribution for ${ }^{252} \mathrm{Cf}$ source. Form of Watt distribution is shown in Fig. 4. The mean of source energy distribution is $\sim 2.3 \mathrm{MeV}$.
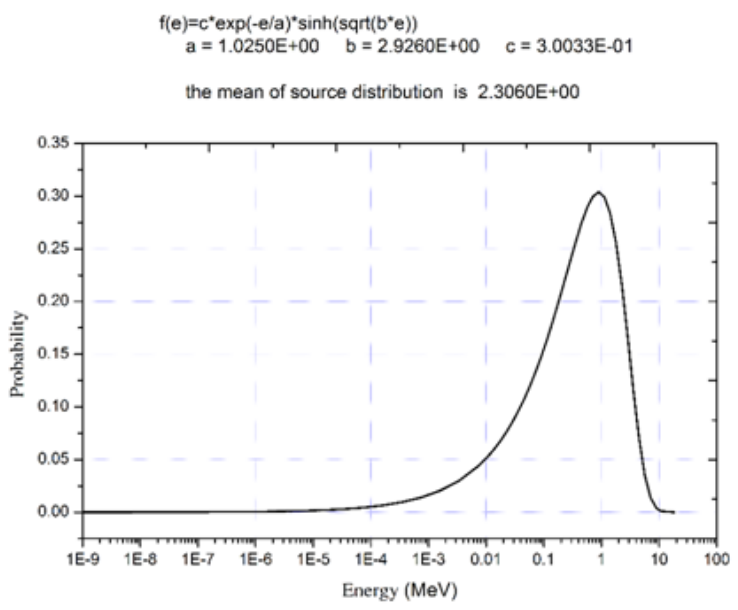

Fig. 4. Energy distribution of ${ }^{252} \mathrm{Cf}$ neutron source. The average energy of the ${ }^{252} \mathrm{Cf}$ neutron source is given in order to evaluate the impact of neutron scattering near the howitzer 


\section{Howitzer}

Howitzer geometry built by MCNP 5 program is shown in Fig. 5 .

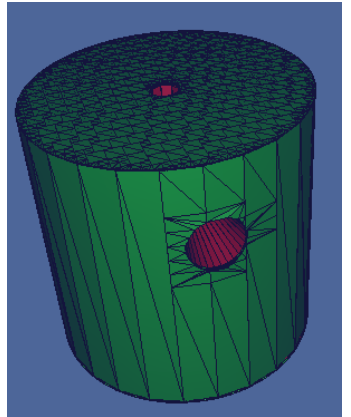

Howitzer

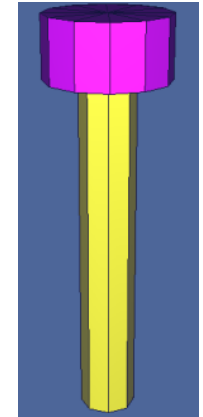

Howitzer lid

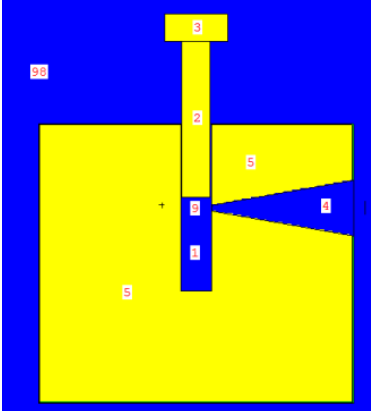

2D image of Howitzer

Fig. 5. Howitzer geometry built by MCNP 5 program

Neutron cross-section library " $60 \mathrm{c}$ " was used. Mass density of paraffin and carbide boron mixture was $1.2 \mathrm{~g} / \mathrm{cm}^{3}$.

\section{Calculations}

Based on the above simulation configuration, the following calculations were performed:

Neutron dose rate and gamma dose rate around the howitzer in both case: source open and source close (Cell 60, 61, 62, 70, 71, 72, 80, 81, and 82 in Fig. 6).

Neutron dose rate and gamma dose rate on neutron beam at different distances from source (Cell 901, 902, 903, 904, 905, 906 in Fig. 6).
Neutron energy distribution on neutron beam at different distances from sources: $27 \mathrm{~cm}, 77$ $\mathrm{cm}, 127 \mathrm{~cm}, 177 \mathrm{~cm}, 227 \mathrm{~cm}$ and $277 \mathrm{~cm}$ corresponding with cell 901, 902, 903, 904, 905, and 906, respectively in Fig. 6.

Cells for dose rate calculation were defined in sphere form. Calculated cells on beam were defined in the form of thin gold foil. Therefore, the simulation results can be compared with the experimental measurement ones.

The number of histories to transport was $10^{10}$ and energy cut-off was set at $10^{-10} \mathrm{MeV}$.

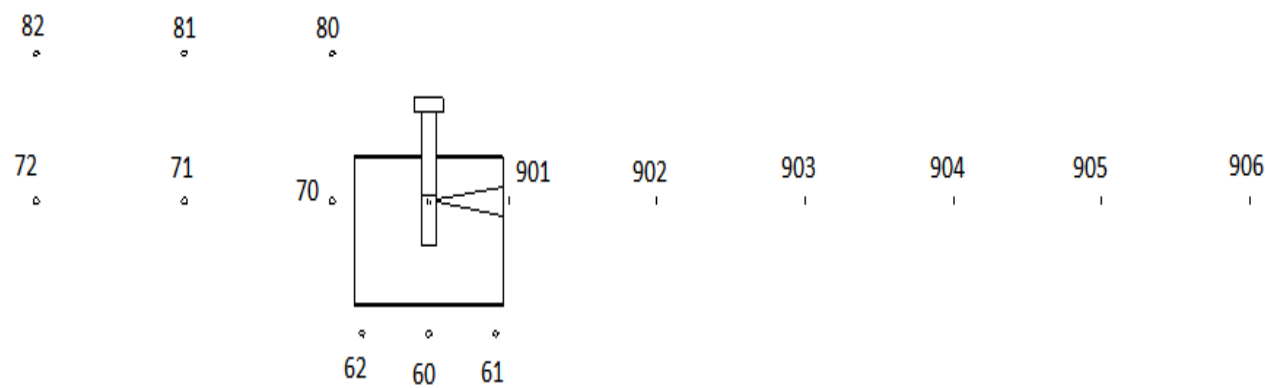

Fig. 6. Position of calculated cells

\section{Trang 86}




\section{RESULTS AND DISCUSSION}

\section{Radiation safety conditions}

Distribution of neutron dose rate and gamma dose rate around the howitzer is shown in Table 1.

Table 1. Dose rate around the howitzer in case of source open

\begin{tabular}{|c|c|c|}
\hline Position & $\begin{array}{l}\text { Neutron dose rate } \\
(\boldsymbol{\mu s} \boldsymbol{V} / \boldsymbol{h})\end{array}$ & $\begin{array}{l}\text { Gamma dose } \\
\text { rate }(\boldsymbol{\mu} \boldsymbol{s} \boldsymbol{V} / \boldsymbol{h})\end{array}$ \\
\hline 60 & $5.1 \pm 0.1$ & $2.14 \pm 0.02$ \\
\hline $\mathbf{6 1}$ & $\mathbf{2 5 . 0} \pm \mathbf{1 . 0}$ & $1.02 \pm 0.01$ \\
\hline 62 & $4.7 \pm 0.2$ & $1.03 \pm 0.02$ \\
\hline $\mathbf{7 0}$ & $\mathbf{6 1 . 3} \pm \mathbf{0 . 9}$ & $5.99 \pm 0.03$ \\
\hline 71 & $7.6 \pm 0.3$ & $0.83 \pm 0.01$ \\
\hline 72 & $3.0 \pm 0.2$ & $0.31 \pm 0.01$ \\
\hline $\mathbf{8 0}$ & $\mathbf{5 5 . 6} \pm \mathbf{0 . 8}$ & $2.63 \pm 0.02$ \\
\hline 81 & $6.9 \pm 0.3$ & $0.59 \pm 0.01$ \\
\hline 82 & $3.0 \pm 0.2$ & $0.27 \pm 0.01$ \\
\hline
\end{tabular}

According to current radiation safety rules in Vietnam [7], radiation worker is allowed to work 8 hours per day if the radiation dose rate is less than $10 \mu \mathrm{s} V / h$. Gamma dose rates of all the positions around the howitzer are less than 10 $10 \mu \mathrm{sV} / \mathrm{h}$. Most of the positions have neutron dose rate less than $10 \mu \mathrm{sV} / \mathrm{h}$. Only three cells 61, 62 , and 80 have neutron dose rate more than $10 \mu s V / h$. These positions are very near the surface of the howitzer, where users do not usually work for a long time.

Therefore, we can conclude that the howitzer design satified the radiation safety rules.

\section{Neutron energy distributions at on beam positions}

The neutron energy distributions and neutron flux of on beam positions are shown in Fig. 7 and Table 2. Number of energy bin is 55 in the energy range from $10^{-10} \mathrm{MeV}$ to $25 \mathrm{MeV}$ and bin size is inhomogeneous. Some gab appear on spectrum can be caused by the inhomogeneous bin size.

Table 2. Neutron flux and average energy at on beam positions

\begin{tabular}{|c|c|c|}
\hline $\begin{array}{l}\text { Calculated } \\
\text { cell }\end{array}$ & $\begin{array}{l}\text { Simulation flux } \\
\text { neutron } \\
\left(\mathbf{n . c m}^{-2} \cdot \mathbf{s}^{-1}\right)\end{array}$ & $\begin{array}{l}\text { Average } \\
\text { energy } \\
(\mathbf{M e V})\end{array}$ \\
\hline 901 & $4210.0 \pm 0.8$ & 1.96 \\
\hline 902 & $434.0 \pm 0.3$ & 2.16 \\
\hline 903 & $155.0 \pm 0.2$ & 2.18 \\
\hline 904 & $78.8 \pm 0.1$ & 2.19 \\
\hline 905 & $47.2 \pm 0.1$ & 2.19 \\
\hline 906 & $31.3 \pm 0.1$ & 2.20 \\
\hline
\end{tabular}

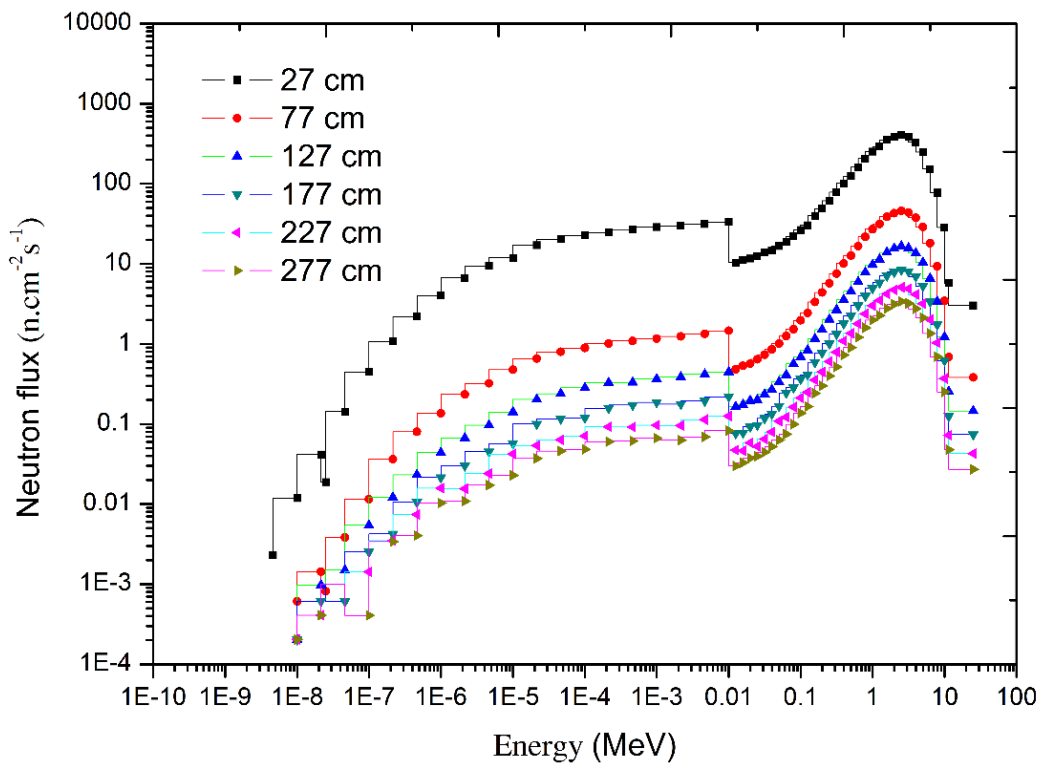

Fig. 7. Neutron energy distribution at on beam positions 
According to data in Table 2, neutron flux decreases when the distance to the source increases. The average neutron energy is 2.3 $\mathrm{MeV}$ at source position, decreases to $1.96 \mathrm{MeV}$ at $27 \mathrm{~cm}$ position, then increases to $2.16 \mathrm{MeV}$ at $77 \mathrm{~cm}$ position, and finally slowly increases from 2.16 $\mathrm{MeV}$ to $2.20 \mathrm{MeV}$ at $277 \mathrm{~cm}$ position. The fact that the average energy at calculated cells is less than the average energy from source is due to the contribution of scattered neutrons. At cell 901, the distance from source is only $27 \mathrm{~cm}$, therefore contribution of scattered neutrons is significant. The importance of this contribution on neutron spectrum is reduced by distance.

Table 3 compares simulation neutron flux with the neutron flux, which is calculated by inverse-square law. At $27 \mathrm{~cm}$ position, the difference between simulation and inverse square law is about $48 \%$, then decrease to $24 \%$ at 77 $\mathrm{cm}$ position, and only $16 \%$ at $277 \mathrm{~cm}$ position. The fact again proves the effect of scattered neutron. The neutron dose rates given in Table 4 match the neutron energy distributions, which are shown in Fig. 7.

Table 3. Comparision between simulation neutron flux to one calculated by inverse-square law

\begin{tabular}{|l|c|c|c|}
\hline Cell & Simulation flux (1) & Inverse-square law calculated flux (2) & $\mathbf{( 1 ) / ( 2 )}$ \\
\hline 901 & $4210.0 \pm 0.8$ & 2839 & 1.48 \\
\hline 902 & $434.0 \pm 0.3$ & 349 & 1.24 \\
\hline 903 & $155.0 \pm 0.2$ & 128 & 1.21 \\
\hline 904 & $78.8 \pm 0.1$ & 66 & 1.19 \\
\hline 905 & $47.2 \pm 0.1$ & 40 & 1.17 \\
\hline 906 & $31.3 \pm 0.1$ & 26 & 1.16 \\
\hline
\end{tabular}

\section{Neutron dose rate at on beam positions}

Table 4. Neutron dose rate at on beam positions

\begin{tabular}{|l|c|}
\hline Cell & Neutron dose rate $(\boldsymbol{\mu S v} / \mathbf{h})$ \\
\hline 901 & $4600.0 \pm 1.0$ \\
\hline 902 & $509.5 \pm 0.4$ \\
\hline 903 & $183.5 \pm 0.2$ \\
\hline 904 & $93.2 \pm 0.2$ \\
\hline 905 & $55.9 \pm 0.1$ \\
\hline 906 & $37.1 \pm 0.1$ \\
\hline
\end{tabular}

This howitzer design allows us to easily and safely set up many experiments such as determination of neutron dose attenuation in solid materials, experiments with phantom for dose evaluation, neutron spectrum measurement, etc.
Therefore, the howitzer system is useful not only for research but also for education purposes.

\section{CONCLUSION}

The simulation results were completely explained by fundamental theory. Thus, the simulation is highly reliable.

The design of the howitzer makes the experiment setting up conveniently, ensures the safety for the employee, and satisfies current financial position of the Training Center.

The howitzer system, if approved, will certainly contribute to complete a set of scientific tools for isotopic neutron source-related research and education.

\section{Trang 88}




\section{Thiết kế và đánh giá buồng chứa nguồn neutron phục vụ nghiên cứu và đào tạo sử dụng chương trình MCNP5}

- Trương Văn Minh

Đại học Đồng Nai

- Nguyễn Ngọc Anh

- Hồ Hũ̃u Thắng Nguyễn Xuân Hải

Viện Nghiên cứu hạt nhân Đà Lạt

- Đinh Tiến Hùng

Viện hóa học và kỹ thuật môi trường quân sự

\section{TÓM TẮT}

Trong bài báo này, đánh giá thiết kế của thùng chứa notron phuc vu muc đích nghiên cúu và đào tại tại Trung tâm đào tạo, Viện Nghiên cưu hạt nhân được trình bày. Hỗn hợp paraffin và boron đurợc sủ dụng vói vai trò là chất làm chậm và chất hấp thu để che chắn notron sinh ra đuợc chế tạo bằng thép để che chắn gamma phát ra do phản úng bắt notron của boron. Công cu mô phỏng được sủ̉ dụng là chuoong trình MCNP5. Các kết quả thu được chỉ ra rằng thiết kế này đáp ưng được các yêu cầu sủ dụng cũng nhu các quy tắc an toàn búc xa tại Việt Nam. tù̀ nguồn 252Cf. Vỏ bọ của thùng chứa notron

Keywords: buồng chưa neutron, buồng chưa sáp nến, thiết kế buồng chứa neutron.

\section{REFERENCES}

[1].M. Pracy, A. Haque, Neutron howitzer design, Nucl. Instruments Methods, 135, 217-221 (1976).

[2].N.V. Hùng, Nghiên cứu, thiết kế và chế tạo hệ thống thiết bị thực nghiệm để đo một số đặc trưng vật lý neutron, phân tích kích hoạt và định liều neutron phục vụ công tác đào tạo nhân lực hạt nhân, Báo cáo tổng kết đề tài cấp Bộ (2011).

[3].Californium-252 neutron source, Certificate No. 19744 for sealed radionuclide source, JSC State Scientific Centre, Research Institute of Atomic Reactors.

[4].F. Brown, B. Kiedrowski, J. Bull, "MCNP51.60 Release Notes", Los Alamos Natl. Lab. LA-UR-IO-06235 (2010).

[5].X-5 Monte Carlo Team, "MCNP - A General N-Particle Transport Code", Version 5 - Vol II: "User's Guide", LA-UR-03-1987, Los Alamos National Laboratory (2003).

[6].http://www.pnnl.gov/main/publications/extern al/technical_reports/PNNL-15870Rev1.pdf.

[7].An toàn bức xạ - giới hạn liều đối với nhân viên bức xạ và dân chúng, TCVN 6866:2001. 